Article

\title{
Cooperative structure-directing effect of choline cation and *BEA zeolite in the synthesis of aluminogermanosilicate IWR zeolite
}

\author{
Wenhua Fu a,b, Zhiqing Yuan a, Shaoqing Jin a, Wei Liu a, Zhendong Wang a, Chuanming Wang a, \\ Yangdong Wang a, Weimin Yang a,*, Ming-Yuan He b,\# \\ a State Key Laboratory of Green Chemical Engineering and Industrial Catalysis, Sinopec Shanghai Research Institute of Petrochemical Technology, \\ Shanghai 201208, China \\ bShanghai Key Laboratory of Green Chemistry and Chemical Processes, School of Chemistry and Molecular Engineering, East China Normal University, \\ Shanghai 200062, China
}

\section{A R T I C L E I N F O}

\section{Article history:}

Received 7 January 2019

Accepted 26 January 2019

Published 5 June 2019

\section{Keywords:}

\section{IWR zeolite}

Cooperative structure-directing effect

Organic structure-directing agent

Choline cation

Heterogeneous seeds

*BEA zeolite

\begin{abstract}
A B S T R A C T
In this contribution, we report the cooperative structure-directing effect of choline hydroxide and aluminosilicate *BEA zeolite in the synthesis of aluminogermanosilicate IWR zeolites for the first time. *BEA zeolites, at variance with any other aluminosilicate zeolites, can serve as heterogeneous seeds for the growth of IWR zeolites and play a cooperative structure-directing role. The crystallization process was investigated using multiple techniques to characterize a series of solid products obtained with various crystallization times. The experiments clearly showed the dissolution of the *BEA zeolite and of an intermediate CDO-type structure. A plausible mechanism for the novel cooperative synthesis has been proposed. The crystallization of the IWR zeolite involves several steps, among which the crucial one is believed to be the reassembly of the building units produced from the decomposition of *BEA zeolite seeds, induced by choline molecules. Having similar structure and common building units (four-, five-, and six-membered rings) with the IWR zeolite, the *BEA zeolite is capable of promoting the reassembly of the building units and can thus play a cooperative structure-directing role. By highlighting the cooperative structure-directing effect of organic molecules and heterogeneous seeds, this study opens up new perspectives for the synthesis of target zeolites that are difficult to prepare by traditional methods. This new synthetic route is also expected to shed light on the discovery of novel zeolites.
\end{abstract}

(C) 2019, Dalian Institute of Chemical Physics, Chinese Academy of Sciences. Published by Elsevier B.V. All rights reserved.

\section{Introduction}

Zeolites are widely used in catalysis, ion exchange, gas adsorption, and separation. The hydrothermal synthesis of zeolites usually requires the addition of structure-directing agents to the synthesis gel. Among these agents, organic molecules such as quaternary ammonium cations, known as organic structure-directing agents (OSDAs), have been extensively studied. The introduction of OSDAs in zeolite synthesis has enabled the preparation of high-silica zeolites and favored the discovery of new zeolite structures [1,2]. The structure-directing effect involves organic molecules organizing the oxide tetrahedral units ( $\mathrm{TO}_{4}$, where $\mathrm{T}$ is a framework element) into a particular geometry around them, thus providing build-

\footnotetext{
* Corresponding author. Tel: +86-21-68462197; E-mail: yangwm.sshy@sinopec.com

\# Corresponding author. Tel: +86-21-62232213; E-mail: hemingyuan@126.com

This work was supported by the National Key R\&D Program of China (2017YFB0702800), National Natural Science Foundation of China (21802168, 21503280, 21603277), and China Petrochemical Corporation (Sinopec Group).

DOI: S1872-2067(19)63324-3 | http://www.sciencedirect.com/science/journal/18722067 | Chin. J. Catal., Vol. 40, No. 6, June 2019
} 
ing blocks for the crystallization of a particular structure type [3]. The organic guest molecules are entrapped into the channels and/or voids of the host zeolite framework and thus contribute to the stability of the guest/host structures by maximizing the non-bonded interactions between them [4-6].

Solid zeolite seeds are often utilized in the synthesis of zeolites, with the purpose to: (i) enhance the crystallization rate, (ii) suppress the formation of undesired phases, and (iii) control the crystal sizes [7]. Xiao's group [8] reported the fast synthesis of *BEA zeolites in the absence of organics, developing the so-called OSDA-free seed-assisted methodology to prepare zeolite materials. The applicability of the seed-assisted synthesis has proved to be quite broad, and a variety of zeolite structures have been prepared using this new method [9-14]. Xiao's group [15] then defined zeolite seeds as a third type of structure-directing agents, to distinguish them from conventional inorganic and organic ones. Based on their crystal structure, the structure-directing seeds can be divided into isomorphous and heterogeneous, where the former have the same crystal structure as the product zeolite, while the latter are seeds with a different framework structure from the target zeolite [16,17]. The crystal growth mechanism of seed-assisted synthesis has been investigated by several groups [18]. Xie et al. [19] and Yashiki et al. proposed a core-shell growth mechanism for the seed-assisted synthesis of *BEA and LEV zeolites, respectively. Okubo's group [20,21] found that a new *BEA zeolite mainly crystallized on the surface of the residual *BEA seeds after their partial dissolution during hydrothermal treatment. $\mathrm{Yu}$ et al. [22] proposed a similar crystallization mechanism in their report on the seed-assisted synthesis of ZSM-5 zeolites. Unlike OSDA molecules, crystal seeds are partially or completely dissolved during the hydrothermal synthesis [23].

In terms of mechanism, the structure-directing effect of OSDA and crystal seeds in the zeolite synthesis can be regarded as constructive and destructive, respectively. From a mechanistic perspective, both kinds of structure-directing agents control the zeolite structure by inducing the formation of particular building units for the crystallization of the target zeolite. Based on this premise, we may expect a cooperative structure-directing effect of OSDAs and crystal seeds under certain conditions. Inspired by the cooperative structure-directing effect of two different OSDAs [24-29], various syntheses employing a combination of organic molecules and solid seeds have been reported. For example, Valtchev et al. [30] reported the "inductive effect" of as-synthesized UTD-1 seeds on the crystallization of SSZ-24 zeolites, where the addition of UTD-1 seeds accelerated the zeolite nucleation and led to the formation of pure and well-crystallized SSZ-24. On the other hand, the $\mathrm{N}, \mathrm{N}, \mathrm{N}$-trimethyl-1-adamantanammonium OSDA utilized in this synthesis had originally been proven to be effective in directing the crystallization of SSZ-24 zeolites by Zones [31]. Taking this aspect into account, the role of the as-synthesized UTD-1 seeds was probably to suppress the formation of undesired phases, rather than to cooperatively direct the zeolite structure. The combined use of OSDA and isomorphous seeds in zeolite synthesis can also be found in the literature. Suzuki and Hayakawa [32] presented the hydrothermal synthesis of
ZSM-48 using tetramethylammonium $\left(\mathrm{TMA}^{+}\right)$ions with the addition of ZSM-48 seeds. Very recently, Okubo's group [33] proposed a rational synthesis route for MSE-type zeolites, where tetraethylammonium hydroxide (TEAOH) was used as a simple OSDA in place of the conventional $N, N, N^{\prime}, N^{\prime}$-tetraethylbicyclo[2.2.2] oct-7-ene-2,3:5,6-dipyrrolidini um complex, while a calcined MCM-68 zeolite (also of MSE-type) served as seed. The same group [34] also reported the synthesis of aluminoborosilicate CON-type zeolites employing TEAOH as OSDA and as-synthesized CIT-1 (also of CON-type) seed crystals in an ( $\mathrm{Na}, \mathrm{K})$-containing gel. In these contributions, the authors reported that the simultaneous presence of isomorphous seeds and OSDA was essential for the crystallization of the target zeolites. However, after a deeper analysis, we suggest that the zeolite seeds probably play the dominant role in directing the structure, based on the fact that these zeolites can also be prepared by the seed-assisted OSDA-free synthesis method [35]. In other words, the OSDA and the isomorphous seeds do not strictly have a cooperative structure-directing role. The underlying concept behind the cooperative directing effect is that the target zeolite structure cannot be controlled by the OSDA or crystal seeds separately, and can only be obtained by their combined use. These observations led us to design a novel synthetic strategy based on the cooperative structure-directing effect of OSDA and heterogeneous, rather than isomorphous, seeds.

Recently, IWR-type framework zeolites have attracted much attention because of their interconnected $12 \times 10 \times$ 10-membered-ring three-dimensional multipore system, which is believed to benefit industrial catalysis processes, such as the alkylation of aromatics [36-38]. The conventional synthesis of IWR zeolites requires the presence of silicon, germanium, and aluminum sources along with the specific hexamethonium OSDA [39]. Taking into account the presence of $\mathrm{Al}$ atoms in the framework of IWR zeolites, we attempted to prepare these structures by using aluminosilicate zeolites as Al sources. Compared to conventional aluminum sources such as aluminum isopropoxide, aluminosilicate zeolites may dissolve in the aqueous solution at a much slower rate, gradually releasing $\mathrm{Al}$ species into the liquid phase. As a result, the interactions between OSDA and Al species, if any, can be controlled. Aluminosilicate zeolites may also play a cooperative structure-directing role in the hydrothermal synthesis, thus facilitating the crystallization of IWR zeolites when a less specific OSDA is employed instead of hexamethonium.

In this contribution, we report for the first time the cooperative structure-directing effect of choline hydroxide and aluminosilicate *BEA zeolites in the synthesis of IWR zeolites. We investigated the effects of OSDAs and aluminum sources on the zeolite framework structure. The crystallization process was then investigated using multiple techniques for characterizing a series of solid products obtained after crystallizing the IWR zeolite for different periods of time. A crystallization mechanism was also proposed, to clarify the role of this novel cooperative directing route in zeolite synthesis.

\section{Experimental}




\subsection{Chemical reagents}

Choline hydroxide was purchased from J\&K Chemicals, Ltd. Tetraethyl orthosilicate (TEOS), germanium oxide, and aluminum isopropoxide were purchased from Sinopharm Chemical Reagent Co., Ltd., China. Aluminosilicate zeolites were obtained from Nankai Catalysis Co., Ltd., China. All chemicals were used as received without further purification.

\subsection{Synthesis of materials}

In a typical synthesis of the IWR zeolite, $2.693 \mathrm{~g}$ of aqueous solution of choline hydroxide $\left(\mathrm{Ch}^{+} \mathrm{OH}^{-}\right), 1.046 \mathrm{~g}$ of germanium oxide, $2.3 \mathrm{~g}$ of TEOS, and $0.66 \mathrm{~g}$ of aluminosilicate H-type zeolite ${ }^{*} \mathrm{BEA}\left(\mathrm{SiO}_{2} / \mathrm{Al}_{2} \mathrm{O}_{3}=25\right)$ were added to a Teflon container. The mixture was hydrolyzed under stirring in a closed configuration. Then, the top of the container was opened to allow ethanol and some water to evaporate. After weighing the container, deionized water was added to obtain a synthesis gel with the following molar composition: $0.5 \mathrm{Ch}^{+} \mathrm{OH}^{-}: 1.1 \mathrm{SiO}_{2}: 0.5$ $\mathrm{GeO}_{2}: 0.02 \mathrm{Al}_{2} \mathrm{O}_{3}: 5 \mathrm{H}_{2} \mathrm{O}$, containing $50 \mathrm{wt} \%$ seeds with respect to the silica content. The $\mathrm{SiO}_{2} / \mathrm{Al}_{2} \mathrm{O}_{3}$ molar ratio was adjusted by changing the proportion of seeds in the synthetic gel. The Teflon liner was then closed, sealed in a stainless steel autoclave, placed in a rotating oven, and heated at $443 \mathrm{~K}$ for $7 \mathrm{~d}$. The solids were recovered by centrifugation, washed with deionized water, and dried at $373 \mathrm{~K}$ overnight. The OSDA was removed by calcining the product in air at $823 \mathrm{~K}$ for $5 \mathrm{~h}$. A high yield $(>80 \%)$ of well-crystallized solid products was then obtained.

\subsection{Characterization}

Powder X-ray diffraction (XRD) patterns were recorded on a PANalytical X'Pert PRO diffractometer with $\mathrm{Cu} K_{\alpha}$ radiation, operated at $40 \mathrm{kV}$ and $40 \mathrm{~mA}$ in the $2 \theta$ range of $5^{\circ}-35^{\circ}$. Scanning electron microscopy (SEM) measurements were performed on a Hitachi S-4800 field-emission scanning electron microscope (Hitachi, Japan) with an acceleration voltage of 3 $\mathrm{kV}$. UV Raman spectra excited at $325 \mathrm{~nm}$ were obtained on a Horiba Jobin-Yvon (LabRAM ARAMIS) Raman spectrograph with a spectral resolution of $2 \mathrm{~cm}^{-1}$. ${ }^{29} \mathrm{Si}$ and ${ }^{27} \mathrm{Al}$ magic angle spinning nuclear magnetic resonance (MAS NMR) measurements were performed using a Varian-400 spectrometer. ${ }^{29} \mathrm{Si}$ NMR spectra were obtained at $79.4 \mathrm{MHz}$ using a 4-mm MAS probe with a spinning rate of $10 \mathrm{kHz}$. Chemical shifts were referenced to 4,4-dimethyl-4-silapentane sodium sulfonate (DSS). A total of 4096 scans were accumulated with a $\pi / 4$ pulse width of $2 \mu \mathrm{s}$ and a $15 \mathrm{~s}$ recycle delay. ${ }^{27} \mathrm{Al}$ NMR spectra were recorded with a frequency of $104.18 \mathrm{MHz}$, a spinning rate of $10.0 \mathrm{kHz}$, and a recycling delay of $4 \mathrm{~s}$. $\mathrm{KAl}\left(\mathrm{SO}_{4}\right)_{2} \cdot 12 \mathrm{H}_{2} \mathrm{O}$ was used as the chemical shift reference. Nitrogen adsorption isotherms at $77 \mathrm{~K}$ were measured on a Quantachrome Quadrasorb evo volumetric adsorption analyzer. The samples were outgassed at $573 \mathrm{~K}$ for $6 \mathrm{~h}$ before the measurements. The Brunauer-Emmet-Teller (BET) specific surface area was calculated using adsorption data acquired in a relative pressure $\left(p / p_{0}\right)$ range of $0.01-0.1$, and the total pore volume was determined from the amounts adsorbed at a relative pressure of about 0.99 . Inductively coupled plasma-atomic emission spectrometry (ICP-AES) measurements were performed using a Thermo IRIS Intrepid II XSP atomic emission spectrometer, after dissolving the samples in HF solution.

\section{Results and discussion}

\subsection{Effect of OSDAs and aluminum sources}

A series of simple quaternary ammonium cations were used as OSDAs, instead of hexamethonium. The $\mathrm{C} / \mathrm{N}$ ratios in these organic molecules were in the range of $4-12$. The syntheses were carried out in the presence and absence of the aluminosilicate *BEA zeolite. As shown in Table S1, different zeolite structures were obtained using different quaternary ammonium cations. The presence of the *BEA zeolite in the gel also had a pronounced effect on the zeolite products. In particular, the IWR zeolite could only be obtained when choline hydroxide was employed together with the *BEA zeolite. Most significantly, the present work is the first report of the successful synthesis of IWR zeolites using choline hydroxide as OSDA. In our previous work, we reported the facile synthesis of hydrothermally stable Ge-containing IWR zeolites using diethyldimethylammonium (DEDMA ${ }^{+}$) as OSDA [40]. As choline is commercially available and much cheaper than $\mathrm{DEDMA}^{+}$or any other OSDAs utilized in the literature [41-43], the synthesis presented in this paper is more cost-effective.

The obtained zeolite products were affected not only by the presence of the aluminum source, but also by the kind of $\mathrm{Al}$ source present. We collected and compared a batch of zeolite samples, which were prepared by employing choline hydroxide as OSDA and different kinds of aluminum sources added in the synthesis gels (the initial $\mathrm{SiO}_{2} / \mathrm{Al}_{2} \mathrm{O}_{3}$ molar ratio was about 120). As summarized in Table 1 and shown in Fig. 1, different zeolite framework structures were obtained. The CDO-type zeolite was obtained in the absence of any Al source (sample a, Fig. 1a) and in the presence of the MOR zeolite (sample b, Fig. 1b). The CDO zeolite was also the main product obtained from the synthesis gel containing ZSM-5 or MCM-22 zeolites as aluminum source (samples $c$ and d, Fig. 1c and 1d). Some minor diffraction peaks assigned to these two zeolites could also be observed, indicating their incomplete dissolution. We speculate that the addition of MOR, ZSM-5, and MCM-22 zeolites did not affect the zeolite crystallization phase region and thus led to the

\section{Table 1}

Products of zeolite syntheses performed using choline hydroxide as OSDA along with different aluminum sources.

\begin{tabular}{lcc}
\hline Sample & Al source & Product \\
\hline $\mathrm{a}$ & None & CDO \\
$\mathrm{b}$ & MOR & CDO \\
$\mathrm{c}$ & ZSM-5 & CDO + MFI \\
$\mathrm{d}$ & MCM-22 & CDO + MWW \\
$\mathrm{e}$ & USY & RUT \\
$\mathrm{f}$ & Aluminum isopropoxide & RUT \\
$\mathrm{g}$ & *BEA & IWR \\
\hline
\end{tabular}




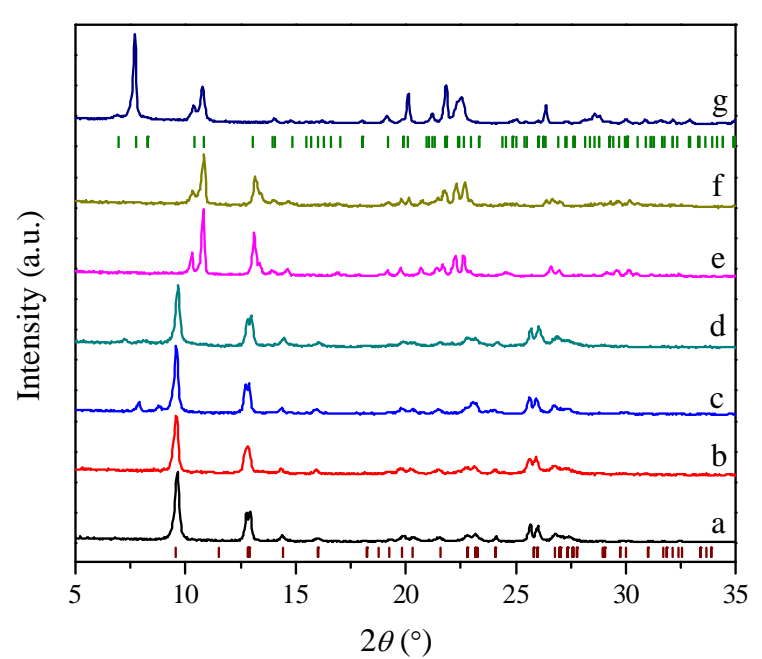

Fig. 1. XRD patterns of zeolites prepared using choline as OSDA and different aluminum sources: none (a), MOR (b), ZSM-5 (c), MCM-22 (d), USY (e), aluminum isopropoxide (f), and *BEA (g). The wine and green bars below pattern a and $\mathrm{g}$ mark the positions of the Bragg reflections of CDO and IWR zeolites, respectively.

growth of the CDO zeolite, which was the same product obtained from the synthesis gel without any aluminum source. The addition of aluminum isopropoxide or USY zeolite in the gel yielded the RUT-type zeolite as product (samples e and f, Fig. 1e and 1f), without the formation of any other zeolite phases. It can be inferred that the USY zeolite acted as normal Al source, with a role similar to that of aluminum isopropoxide. Interestingly, the IWR zeolite product was obtained when the aluminosilicate *BEA zeolite was used as Al source (sample g, Fig. 1g) [36]. No peaks attributed to the *BEA zeolite were found in the pattern, indicating that the crystals were completely dissolved (the XRD patterns of the aluminosilicate zeolites are shown in Fig. S1). To sum up, the *BEA zeolite was the only $\mathrm{Al}$ source able to induce the crystallization of the IWR zeolite.

The different zeolite structures prepared using various kinds of $\mathrm{Al}$ sources could also be distinguished based on their SEM images, as shown in Fig. 2. The CDO zeolite crystals are characterized by a plate-like morphology, with sizes of 2-10 $\mu \mathrm{m}$ (Fig. 2a). The undissolved ZSM-5 and MCM-22 crystals could also be observed in Fig. 2c-d (the SEM images of the aluminosilicate zeolites are shown in Fig. S2). RUT zeolites are globular or ellipsoidal aggregates of 2-5 $\mu \mathrm{m}$ size arising from the superposition of nanoparticles (Fig. 2e-f). The IWR zeolite prepared with using the *BEA structure consists of self-pillared or so-called "house-of-cards" nanosheets crystals, with sizes of $100 \mathrm{~nm} \times 400 \mathrm{~nm}$ and thicknesses of about $30 \mathrm{~nm}$ (Fig. 2g). No residual *BEA crystals, consisting of nanocrystals of size below $100 \mathrm{~nm}$ and their aggregates, were present in the products, which is in agreement with the XRD results.

Based on its distinct effect from that of aluminum isopropoxide and other zeolites, the role of the *BEA zeolite should be revisited. A more accurate way to term the *BEA zeolite would be "heterogeneous seeds", rather than the ordinary "aluminum source", to highlight its structure-directing role in the synthesis of the IWR zeolite. The IWR zeolite was not obtained in the absence of either choline hydroxide or *BEA zeolite, thus evidencing their cooperative structure-directing role in the crystallization process. Notably, this is the first report of a cooperative structure-directing effect involving an OSDA and heterogeneous seeds. This finding represents a new example of a cooperative structure-directing effect in the synthesis of microporous materials [44].

\subsection{Investigation of the crystallization process}

In order to validate the synthesis process and elucidate the interaction between the choline hydroxide OSDA and *BEA zeolite heterogeneous seeds, we collected a series of solid products after heating the synthesis gel for different periods of time and analyzed them using multiple characterization techniques. The XRD patterns of the solid products and those of the *BEA zeolite acting as heterogeneous seeds are displayed in Fig. 3. When the heating time was shorter than $8 \mathrm{~h}$, only the undissolved *BEA zeolite was collected, while no other zeolite
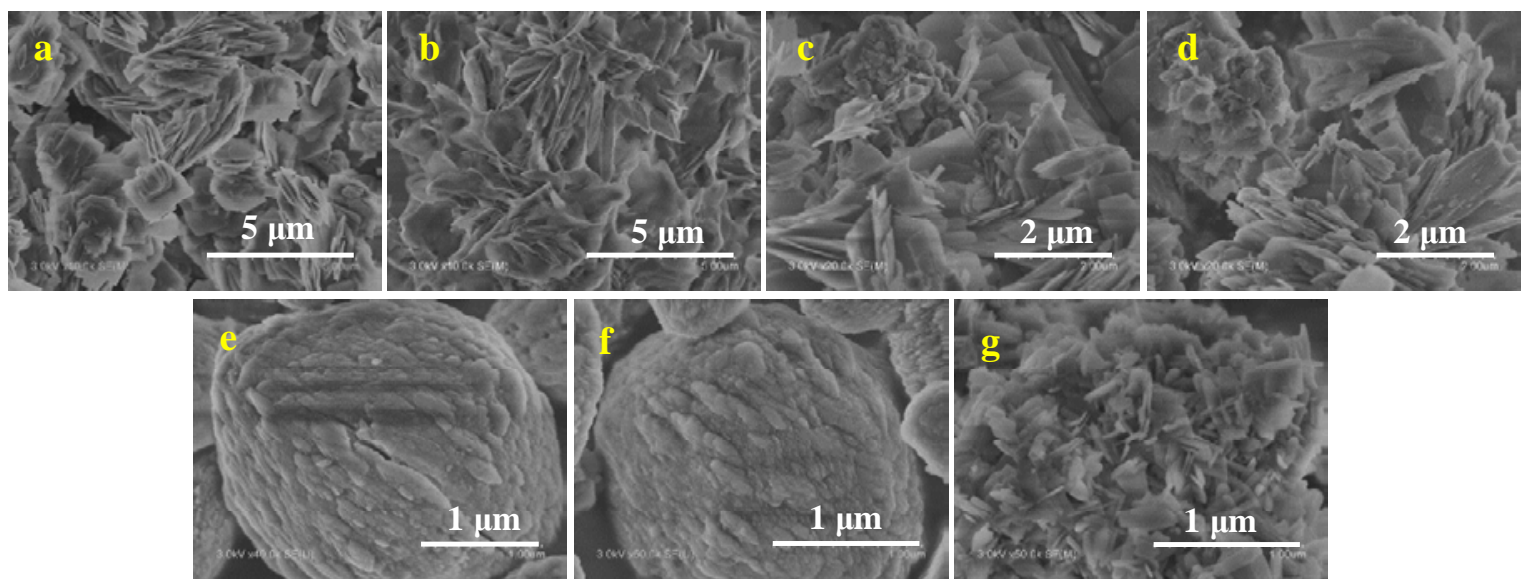

Fig. 2. SEM images of zeolites prepared using choline as OSDA and different aluminum sources: none (a), MOR (b), ZSM-5 (c), MCM-22 (d), USY (e), aluminum isopropoxide (f), and *BEA (g). 


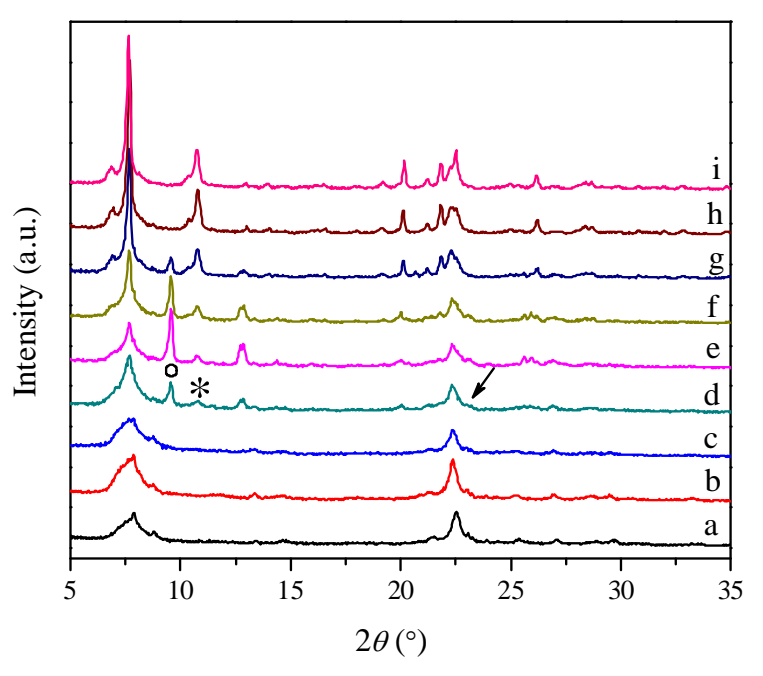

Fig. 3. XRD patterns of (a) *BEA zeolite and (b-i) solid products obtained after heating the synthesis gel for different periods of time: $4 \mathrm{~h}$ (b), 8 h (c), 12 h (d), 24 h (e), 48 h (f), 72 h (g), 120 h (h), and 168 h (i). The circle, asterisk, and arrow symbols above pattern (d) mark the diffraction peaks corresponding to the (020) plane of the CDO zeolite, the (201) plane of the IWR zeolite, and the (311) plane of the *BEA zeolite, respectively.

phases appeared in the products. The degree of crystallinity of the *BEA zeolite decreased with increasing reaction time, indicating the gradual dissolution of seed crystals during the hydrothermal treatment. The diffraction peaks of the *BEA zeolite did not disappear until the synthesis gel was heated for $72 \mathrm{~h}$. The diffraction peaks attributed to the CDO and IWR zeolites emerged at $12 \mathrm{~h}$ (Fig. 3d). The intensity of the CDO zeolite peaks increased upon extending the reaction time from 12 to $24 \mathrm{~h}$, then decreased and eventually disappeared at $120 \mathrm{~h}$, which indicates that the CDO zeolite was an intermediate phase during the crystallization process. After their appearance at 12 $\mathrm{h}$, the diffraction peaks of the IWR zeolites showed increasing intensities. The crystallization process was completed after 168 $\mathrm{h}$ of hydrothermal synthesis. Further hydrothermal treatment did not result in significant changes in crystallinity. The zeolite phases of the solid products collected at different times are summarized in Table 2. At 12-72 h, more than one zeolite phase was present in the products. Therefore, a detailed analysis of the patterns is essential for the interpretation of the crystallization process. Although the overlapping of diffraction peaks is inevitable, we can identify the three zeolite phases by the specific diffraction peaks at $2 \theta$ angles of ca. $9.6^{\circ}, 10.8^{\circ}$, and $23.0^{\circ}$, which are exclusively attributed to the $(020)$ plane of the CDO zeolite, the (201) plane of the IWR zeolite, and the (311) plane of the *BEA zeolite, respectively (Fig. 3d). The patterns in the $2 \theta$ ranges of $8.5^{\circ}-11.5^{\circ}$ and $21.5^{\circ}-23.5^{\circ}$ have been scaled up in Fig. S3, allowing us to confirm the zeolite phases present in the solid products.

The structural transformation of the products was also observed in the SEM images, as shown in Fig. 4. As mentioned above, the *BEA, CDO, and IWR zeolites can be easily distinguished based on their different morphologies. At the initial
Table 2

Zeolite phase of solid products collected at different heating periods.

\begin{tabular}{lc}
\hline Period (h) & Zeolite phase \\
\hline 4 & ${ }^{*} \mathrm{BEA}$ \\
8 & ${ }^{* B E A}$ \\
12 & *BEA + CDO + IWR \\
24 & *BEA + CDO + IWR \\
48 & *BEA + CDO + IWR \\
72 & CDO + IWR \\
120 & IWR \\
168 & IWR \\
\hline
\end{tabular}

stage of crystallization (0-8 h), only *BEA zeolite crystals and amorphous aggregates were observed (Fig. 4b and 4c). With increasing crystallization time, the amount of *BEA zeolite crystals gradually decreased and finally disappeared at $72 \mathrm{~h}$ (Fig. 4g). Plate-like CDO and self-pillared IWR zeolite crystals emerged at $12 \mathrm{~h}$, and are marked by black circles and white ellipses, respectively, in Fig. 4d. CDO zeolite crystals were observed at $12-72 \mathrm{~h}$ (Fig. $4 \mathrm{~d}-\mathrm{g}$ ) and disappeared at $120 \mathrm{~h}$ (Fig. $4 \mathrm{~h}$ ), suggesting that this type of zeolite was an intermediate product. The proportion of IWR zeolite crystals in the product increased after their formation at $12 \mathrm{~h}$. Once the crystallization time reached $120 \mathrm{~h}$, only the IWR zeolite was present in the products. The SEM images thus provided evidence for: i) the dissolution of *BEA zeolite seed crystals; ii) the appearance and disappearance of CDO zeolite crystals; iii) the growth of the IWR zeolite during the hydrothermal treatment. It is worth noting that these observations are in agreement with the XRD results in Fig. 3.

UV Raman spectroscopy has proved to be a powerful tool for studying catalysts and other solids [45-47]. Owing to the vibrational motion of the framework, the Raman bands are very sensitive to the basic building units and framework structures of zeolites $[48,49]$. The prominent band in the 300-600 $\mathrm{cm}^{-1}$ region in the Raman spectrum of a zeolite has been found
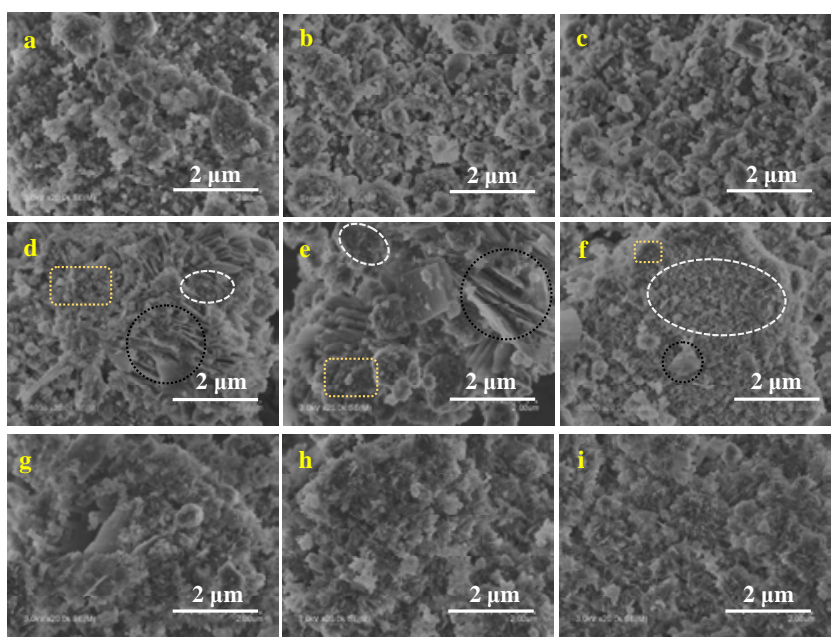

Fig. 4. SEM images of (a) *BEA zeolite and (b-i) solid products obtained after heating the synthesis gel for different periods of time: $4 \mathrm{~h}(\mathrm{~b}), 8 \mathrm{~h}$ (c), $12 \mathrm{~h}$ (d), $24 \mathrm{~h}$ (e), $48 \mathrm{~h}$ (f), $72 \mathrm{~h}$ (g), $120 \mathrm{~h}$ (h), and $168 \mathrm{~h}(\mathrm{i})$. The *BEA, CDO, and IWR zeolite crystals in panels d-f (12-48 h) are marked by yellow rectangles, black circles, and white ellipses, respectively. 
to be sensitive to the ring structures present in the framework $[50,51]$. The UV Raman spectra of the *BEA, CDO, and IWR zeolites are shown in Fig. 5A. The spectrum of zeolite *BEA shows bands at 468, 428, 398, and $345 \mathrm{~cm}^{-1}$. The first two bands are assigned to the bending mode of the characteristic four-membered rings (4MRs), while the bands at 398 and 345 $\mathrm{cm}^{-1}$ are ascribed to the five- and six-membered rings (5MRs and 6MRs), respectively [52]. The 4MRs, 5MRs, and 6MRs are also the building units of the framework of the IWR zeolite and the corresponding bands in the UV Raman spectrum are located at 460, 398, and $345 \mathrm{~cm}^{-1}$, respectively. There are two main differences between the spectra of the *BEA and IWR zeolites. One is that the band at $428 \mathrm{~cm}^{-1}$, ascribed to $4 \mathrm{MRs}$ within the *BEA zeolite framework, is not present in the spectrum of the IWR zeolite. The other is that the band at $468 \mathrm{~cm}^{-1}$ in the spectrum of the *BEA zeolite shifts to a slightly lower wavenumber $\left(460 \mathrm{~cm}^{-1}\right)$ in the spectrum of the IWR zeolite, which may be due to the high content of Ge atoms in the latter. As the 4MRs and 6MRs are not the building units of the CDO zeolite framework, its spectrum only shows a broad band at $443 \mathrm{~cm}^{-1}$ assigned to 5MRs. It is worth mentioning that the largest pore opening in the CDO zeolite is represented by eight-membered rings (8MRs), which hinders the complete release of OSDA molecules trapped within the channels via calcination. The residual organics gave rise to strong fluorescence interference and baseline drift in the spectrum of the CDO zeolite (see Fig. S4A). During the crystallization process, the band at $428 \mathrm{~cm}^{-1}$, which could only be found in the spectrum of zeolite *BEA, disappeared after $72 \mathrm{~h}$ (Fig. 5B), indicating the full dissolution of *BEA seeds at that time, in agreement with the XRD and SEM results (Figs. 3 and 4). The band at $468 \mathrm{~cm}^{-1}$ was shifted to 460 $\mathrm{cm}^{-1}$ after $12 \mathrm{~h}$ of heating, which is likely related to the appearance of CDO and IWR zeolite phases in the products. A noticeable baseline drift associated with the presence of CDO zeolites could be observed in the spectra of solid products collected at 12-72 h (Fig. S4B). The intensity of the bands at 398 and $345 \mathrm{~cm}^{-1}$, assigned to $5 \mathrm{MRs}$ and $6 \mathrm{MRs}$ in *BEA and IWR zeolites, respectively, displayed an initial decreasing trend and a subsequent increase, originating from the decomposition of
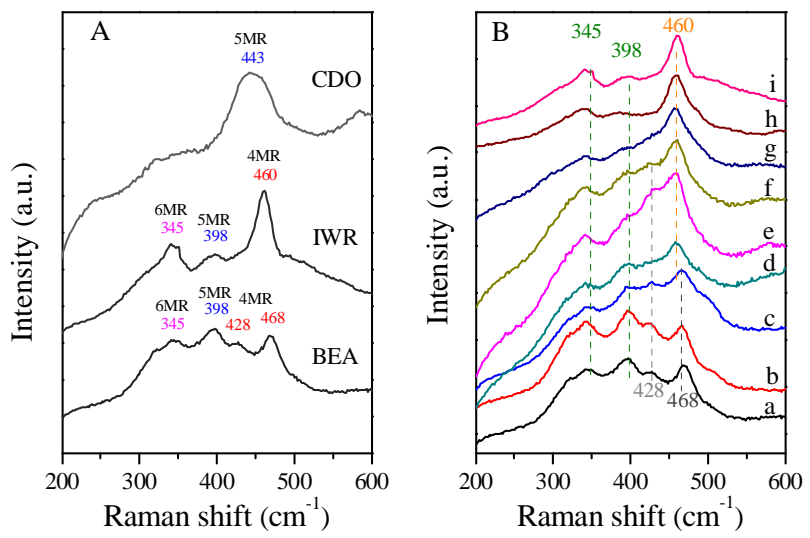

Fig. 5. UV Raman spectra of (A) zeolite materials with different topologies and (B) solid products obtained after heating the synthesis gel for different periods of time: *BEA zeolite (a), $4 \mathrm{~h}(\mathrm{~b}), 8 \mathrm{~h}(\mathrm{c}), 12 \mathrm{~h}(\mathrm{~d}), 24 \mathrm{~h}$ (e), 48 h (f), 72 h (g), 120 h (h), and 168 h (i).
*BEA seeds followed by the growth of the IWR zeolite.

The ${ }^{29}$ Si MAS NMR spectra of the solid products obtained for different crystallization periods together with those of the *BEA zeolite show several signals between $\delta=-100$ and -120 ppm, characteristic of framework silicon atoms in different chemical environments (Fig. 6). Five resonances at ca. -115 , $-110,-106,-102$, and -97 ppm could be resolved in the deconvoluted spectra of all samples. The assignments of the resonance peaks in the spectra of aluminosilicate and germanosilicate zeolites can be different. For *BEA seeds, the resonances at -115 and $-110 \mathrm{ppm}$ are assigned to $\mathrm{Si}(\mathrm{OSi})_{4}\left(\mathrm{Q}^{4}\right)$ sites $[53,54]$. The signals at $-106,-102$, and -97 ppm can be ascribed to $\mathrm{Si}(\mathrm{OSi})_{3}(\mathrm{OAl})\left(\mathrm{Q}^{4}-1 \mathrm{Al}\right), \mathrm{Si}(\mathrm{OSi})_{3}(\mathrm{OH})\left(\mathrm{Q}^{3}\right)$, and $\mathrm{Q}^{4}-2 \mathrm{Al}$ species, respectively [55]. The product collected at $8 \mathrm{~h}$ mainly consisted of undissolved *BEA zeolite, although its crystallinity was lower than that of the parent *BEA seeds (see the XRD patterns in Fig. 3). The concentrations of $\mathrm{Q}^{4}$ and $\mathrm{Q}^{3}$ environments in the *BEA seeds were $69.9 \%$ and $14.8 \%$, respectively, while those in the $8 \mathrm{~h}$ product were $51.2 \%$ and $29.6 \%$ (Table S2). The remarkably lower $\mathrm{Q}^{4}$ and higher $\mathrm{Q}^{3}$ contents compared to those of the *BEA seeds suggested the presence of incompletely connected tetrahedral sites in the $8 \mathrm{~h}$ product, which was associated with the partial decomposition of the *BEA zeolite. The products collected at 72 and $168 \mathrm{~h}$ were classified as germanosilicate rather than aluminosilicate zeolites, since their $\mathrm{Si}$ and Ge contents were much higher than the Al content of the framework (see Table 3). For this kind of zeolites, the resonances at -115 and $-110 \mathrm{ppm}$ are also assigned to $\mathrm{Q}^{4}$ sites, while that at $-106 \mathrm{ppm}$ is assigned to $\mathrm{Q}^{4-1 G e}$ species [56]. The signal at $-102 \mathrm{ppm}$ can be attributed to the overlap of the $\mathrm{Q}^{4}-2 \mathrm{Ge}$ and $\mathrm{Q}^{3}$ groups [57]. The weakest resonance at $-97 \mathrm{ppm}$ was tentatively ascribed to defect $\mathrm{Si}(\mathrm{OSi})_{2}(\mathrm{OGe})^{-}$sites $[58,59]$. A key finding of this work is that as the crystallization period

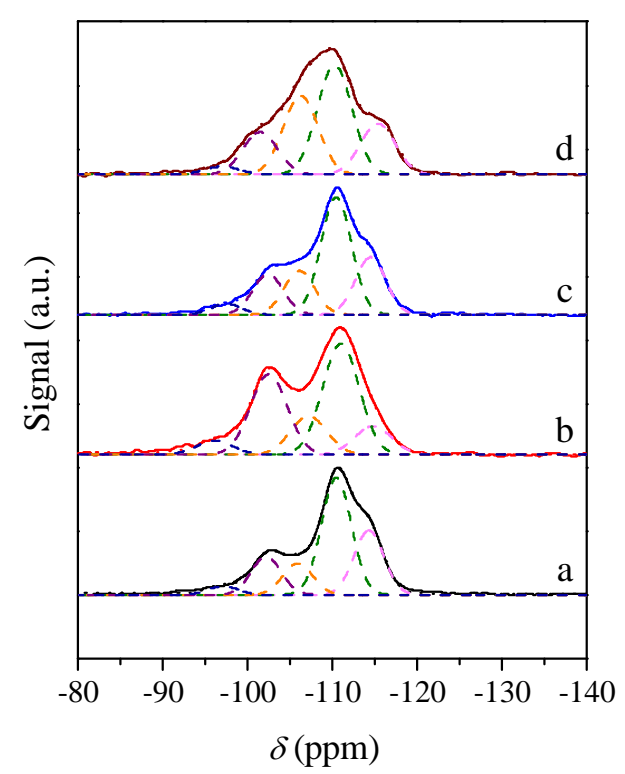

Fig. 6. ${ }^{29}$ Si MAS NMR spectra of (a) *BEA zeolite and (b-d) solid products obtained after heating the synthesis gel for different periods of time: $8 \mathrm{~h}(\mathrm{~b}), 72 \mathrm{~h} \mathrm{(c)}$, and $168 \mathrm{~h}(\mathrm{~d})$. 
Table 3

Chemical compositions and textural properties of *BEA zeolite and solid products obtained after heating the synthesis gel for different periods of time.

\begin{tabular}{|c|c|c|c|c|c|c|c|}
\hline Sample & $\mathrm{Si} / \mathrm{Ge}$ & Ge content ${ }^{\mathrm{a}}(\mathrm{wt} \%)$ & $\mathrm{SiO}_{2} / \mathrm{Al}_{2} \mathrm{O}_{3}$ a & $A_{\mathrm{BET}}{ }^{\mathrm{b}}\left(\mathrm{m}^{2} \mathrm{~g}^{-1}\right)$ & $A_{\text {micro }}{ }^{\mathrm{b}}\left(\mathrm{m}^{2} \mathrm{~g}^{-1}\right)$ & $V_{\text {total }}{ }^{\mathrm{c}}\left(\mathrm{cm}^{3} \mathrm{~g}^{-1}\right)$ & $V_{\text {micro }}{ }^{\mathrm{b}}\left(\mathrm{cm}^{3} \mathrm{~g}^{-1}\right)$ \\
\hline *BEA & - & - & 25 & 494 & 374 & 0.73 & 0.17 \\
\hline $4 \mathrm{~h}$ & 56.3 & 2.0 & 27 & 485 & 398 & 0.47 & 0.18 \\
\hline $12 \mathrm{~h}$ & 18.2 & 5.9 & 49 & 409 & 353 & 0.44 & 0.16 \\
\hline $24 \mathrm{~h}$ & 11.1 & 9.2 & 66 & 423 & 359 & 0.40 & 0.16 \\
\hline $72 \mathrm{~h}$ & 4.5 & 19.0 & 59 & 410 & 332 & 0.49 & 0.15 \\
\hline $168 \mathrm{~h}$ & 3.4 & 23.3 & 52 & 478 & 399 & 0.53 & 0.18 \\
\hline
\end{tabular}

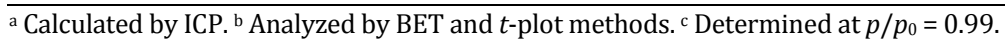

was prolonged from 72 to $168 \mathrm{~h}$, the proportion of $\mathrm{Q}^{4}$ sites in the framework decreased from $64.7 \%$ to $55.3 \%$, while that of $\mathrm{Q}^{4}-1 \mathrm{Ge}$ sites increased from $16.2 \%$ to $27.3 \%$. That means that more Ge atoms were incorporated in the framework. This conclusion was confirmed by the ICP measurements, where the Ge content in the products increased from $19.0 \mathrm{wt} \%$ at $72 \mathrm{~h}$ to $23.3 \mathrm{wt} \%$ at $168 \mathrm{~h}$ (Table 3 ). It is worth noting that, in spite of the structural evolution and the change in chemical composition of the framework, most $\mathrm{Al}$ atoms were incorporated in the framework; in fact, the resonance at about 56 ppm (ascribed to tetrahedrally coordinated Al species) was much more pronounced than that at $0 \mathrm{ppm}$, due to octahedrally coordinated $\mathrm{Al}$ species in the ${ }^{27} \mathrm{Al}$ MAS NMR spectra (see Fig. S5).

The $\mathrm{N}_{2}$ adsorption-desorption isotherms of the solid products collected at different crystallization times are displayed in Fig. 7 and the textural properties of these solids are listed in Table 3. All materials exhibit type I isotherms, characteristic of microporous solids, along with a capillary condensation step above a relative pressure of 0.9 , which is probably due to the intercrystal voids of the nanoparticles. The completely crystallized IWR zeolite (corresponding to the sample collected at 168 h) exhibited almost the same specific surface area $\left(A_{\mathrm{BET}}\right)$ and micropore volume $\left(V_{\text {micro }}\right)$ as the ${ }^{*}$ BEA zeolite (Table 3$)$. The total pore volume $\left(V_{\text {total }}\right)$ of the IWR zeolite was lower than that of the *BEA one, because of the larger crystal size of the former

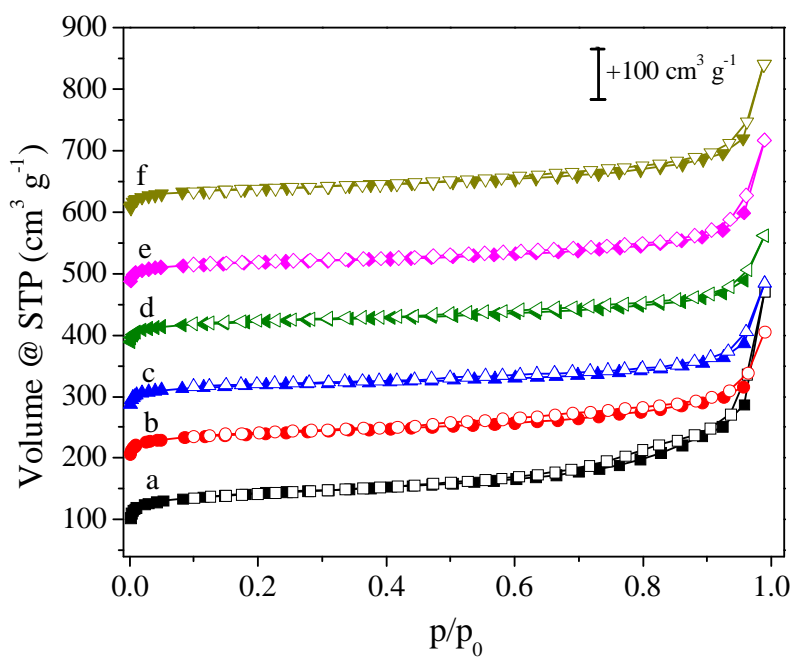

Fig. 7. $\mathrm{N}_{2}$ adsorption-desorption isotherms at $77 \mathrm{~K}$ for (a) ${ }^{*} \mathrm{BEA}$ zeolite and (b-f) solid products obtained after heating the synthesis gel for different periods of time: $4 \mathrm{~h}$ (b), $12 \mathrm{~h} \mathrm{(b),} 24 \mathrm{~h}(\mathrm{~d}), 72 \mathrm{~h}(\mathrm{e})$, and $168 \mathrm{~h}$ (f). The isotherms are offset vertically by $100 \mathrm{~cm}^{3} \mathrm{~g}^{-1}$ for clarity. (see Fig. 4). As discussed in the previous paragraphs, the CDO and IWR zeolites coexisted in the products collected at 12-72 $\mathrm{h}$. Taking into account the narrow open window (two-dimensional $8 \times 8$-membered-ring) and confined porosity, the CDO zeolite exhibited a small specific surface area and micropore volume (see Fig. S6 and Table S3). As a result, the solid products collected at 12-72 $\mathrm{h}$ possessed slightly lower specific surface area and micropore volume compared to the product collected at $168 \mathrm{~h}$. In other words, the measurements of the specific surface area and micropore volume of the materials provided supplementary evidence for the presence of the CDO zeolite in the products obtained at 12-72 $\mathrm{h}$. The chemical compositions of the products are also listed in Table 1 . With increasing crystallization time, the $\mathrm{SiO}_{2} / \mathrm{Al}_{2} \mathrm{O}_{3}$ molar ratios first increased and then decreased, consistent with the decomposition of *BEA seeds followed by incorporation of $\mathrm{Al}$ atoms into the IWR zeolite framework. In addition, the $\mathrm{SiO}_{2} / \mathrm{Al}_{2} \mathrm{O}_{3}$ molar ratio in the fully crystallized IWR zeolite was close to that in the initial gel, indicating a high utilization efficiency of Al species in the *BEA seed crystals. The $\mathrm{Si} / \mathrm{Ge}$ molar ratios kept decreasing during the crystallization process, suggesting the gradual incorporation of Ge atoms.

To sum up, the multiple techniques discussed above clearly demonstrated that the decomposition of *BEA zeolites occurred prior to the assembly of silicate and germanate species. The CDO zeolite was an intermediate phase during the crystallization process. Neither *BEA nor CDO zeolites were observed in the final product, suggesting that a phase transformation stage was involved in the cooperative structure-directing synthesis of IWR zeolites presented in this work.

\subsection{Mechanism of the cooperative structure-directing synthesis}

We proposed that choline hydroxide and *BEA zeolite probably play a cooperative role in directing the crystallization of the IWR zeolite. We also observed a phase transformation process during the synthesis, in which the CDO zeolite was proved to be an intermediate phase and was eventually converted into the IWR zeolite. To obtain deeper insight into the present cooperative directing route, one should determine the driving force for the phase transformation and a plausible mechanism for the crystallization process.

As stated in the Introduction, OSDAs can favor the formation of particular oligomers and precursor species of zeolite structures. Taking into account the fact that the CDO zeolite was obtained in the absence of aluminosilicate zeolites in the syn- 
thesis gel and that the same zeolite was an intermediate phase during the synthesis of the IWR structure, we may infer that the CDO zeolite would be the default product when choline is used as OSDA. As 5MRs are the exclusive building units of the CDO framework, we can speculate that choline molecules prefer to direct the generation of 5MR-based precursor species under the experimental conditions. The validity of this conclusion is substantiated by other studies, where a similar structure-directing behavior of choline molecules was reported. For example, Sano's team [60] reported the synthesis of the CDO-type silicate zeolite precursors HUS-3 and HUS-4 using choline hydroxide as OSDA. Both these silicates exhibited a layered structure and could be converted into the CDO zeolite by calcination. By employing choline as OSDA, Lee et al. [61] successfully prepared the proton form of nanosized, needle-like ferrierite (FER type) zeolites, whose framework consists of the same building units and ferrierite layers as those of the CDO zeolite [62-64].

In the phase transformation stage of the hydrothermal process (12-72 h, when several zeolite phases coexisted), the default CDO zeolite was eventually converted into the IWR zeolite. The CDO zeolite is supposed to be more thermodynamically stable than the IWR one, due to its higher framework density. As a result, the phase transformation is likely to be kinetically controlled. Acting as heterogeneous seeds, the *BEA zeolite is expected to contribute to this process. It has been suggested that the presence of common composite building units (CBUs) in the seed and target zeolites is crucial for the seed-assisted zeolite synthesis [65]. The composite building units of *BEA, CDO, and IWR zeolites are (mor, bea, $m t w)$, (mor, fer), and ( $d 4 r$, bre, lau, mel), respectively (see Fig. S7). The *BEA and CDO zeolites have the mor CBU in common, while the seed *BEA zeolite and the target IWR zeolite seem to have no common CBUs. Nevertheless, we observe that both *BEA and IWR frameworks primarily consist of $4 \mathrm{MR}, 5 \mathrm{MR}$, and 6MR connecting units, which may act as the common building units. According to the structural analysis, the *BEA zeolite is an intergrowth of two distinct but closely related polymorphs, i.e., polymorphs $\mathrm{A}$ and $\mathrm{B}$, in a ratio of ca. 44:56 [66,67]. Polymorph A shows two characteristic XRD peaks at $2 \theta=6.98^{\circ}$ and $7.74^{\circ}$, which are assigned to the (100) and (101) planes, respectively. Interestingly, these two peaks can also be found in the XRD pattern of the IWR zeolite, located at $2 \theta=7.00^{\circ}$ and $7.74^{\circ}$, and indexed to the (001) and (110) planes, respectively (see Fig S8). This suggests that there might be some structural similarity between the *BEA and IWR zeolites. We speculate that the (100) and (101) planes of the *BEA zeolite polymorph A can be related to the (001) and (110) planes of the IWR zeolite, although more evidence is needed. It is worth noting that even though the frameworks of the ZSM-5 and MCM-22 zeolites also contain the primary 4MR, $5 \mathrm{MR}$, and 6MR units, they were proved unable to direct the crystallization of the IWR zeolite. The reason may be that these two kinds of zeolites bear no structural similarity to the target IWR zeolite. In short, the structural similarity of the *BEA and IWR zeolites, together with their common $4 \mathrm{MR}, 5 \mathrm{MR}$, and $6 \mathrm{MR}$ building units, enables the use of *BEA zeolites as heterogeneous seeds in the synthesis of the IWR zeolite.
On the basis of the above results and the corresponding discussion, we propose that the crystallization of the IWR zeolite proceeds through a novel cooperative directing mechanism (Scheme 1). The first stage is the decomposition/dissolution of *BEA seeds, which gives rise to an enormous amount of building units, including 4MRs, 5MRs, and 6MRs (step 1). Owing to the abundant defect sites and appropriate $\mathrm{SiO}_{2} / \mathrm{Al}_{2} \mathrm{O}_{3}$ molar ratio within the framework, the *BEA zeolite could be easily dissolved under alkaline synthesis conditions [20]. It should be noted that the above building units consist of $\mathrm{Si}$ and $\mathrm{Al}$, but no Ge atoms. Afterward, choline molecules induce the formation of polyanion species through the oligomerization of silicate and germanate species in the gel (step 2). Due to the specific directing capability of choline molecules, only 5MR-based building units would be generated in this step. The assembly of these building units results in the formation of the CDO zeolite, with choline molecules occluded in the pores (step 3). At the same time, the CDO zeolite can also be dissolved under alkaline conditions, releasing the 5MR-based building units back into the liquid phase (step 4). The final and also most significant step in the cooperative synthesis of the IWR zeolite is the reassembly of all building units in the presence of choline hydroxide (step 5). The building units were divided into two groups. One contained aluminosilicate 4MRs, 5MRs, and 6MRs arising from the decomposition of *BEA seeds, while the other included germanosilicate 5MRs derived from the oligomerization of silicate-germanate species induced by choline molecules and from the decomposition of the CDO zeolite. Once formed in step 2, the germanosilicate 5MRs could either assemble into the CDO zeolite (step 3) or reassemble with aluminosilicate building

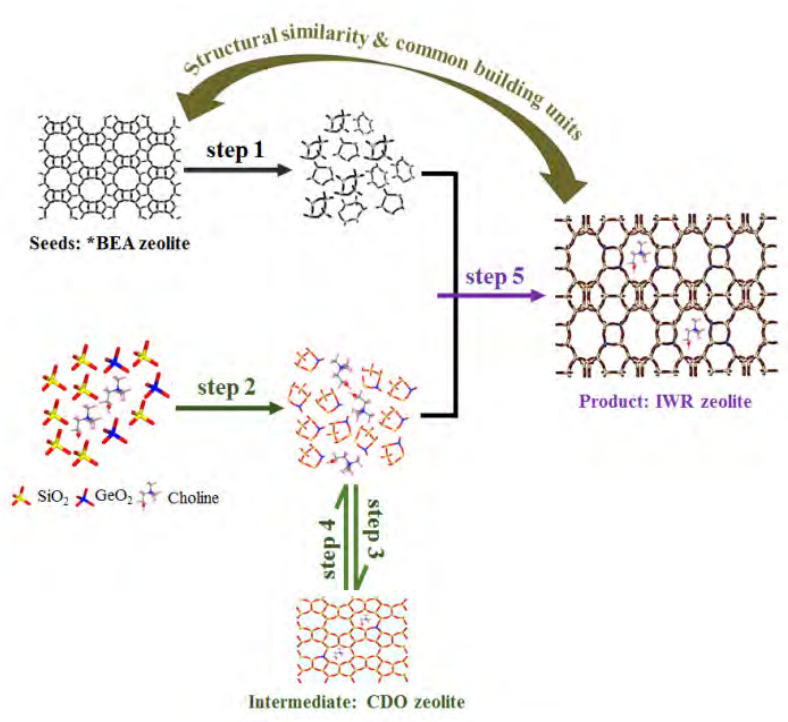

Scheme 1. Proposed cooperative mechanism for crystallization of IWR zeolite using choline hydroxide as OSDA and *BEA zeolite as heterogeneous seed. The scheme involves the following steps: step 1, decomposition/dissolution of *BEA seeds into aluminosilicate $4 \mathrm{MR}, 5 \mathrm{MR}$, and 6MR building units; step 2, choline-induced formation of germanosilicate 5MR units; step 3, assembly of germanosilicate 5MR units into CDO zeolite; step 4, decomposition/dissolution of CDO zeolite into 5MR building units; step 5, reassembly of all aluminosilicate and germanosilicate building units into IWR zeolite product. 
units (step 5). As a result, CDO and IWR zeolites appeared simultaneously at $12 \mathrm{~h}$ (see Figs. 3 and 4). Before $24 \mathrm{~h}$, step 3 prevailed over step 5; consequently, the CDO zeolite-related peaks in the XRD patterns became increasingly more pronounced, as shown in Fig. 3. As the nutrient in the gel was consumed, step 5 prevailed over step 3 . In addition, the participation of $5 \mathrm{MR}$ units released from the CDO zeolite in the reassembly step helped to accelerate the decomposition of the CDO structure (step 4) and thus led to its disappearance after $72 \mathrm{~h}$ of heating. In other words, the reassembly of the building units is expected to be the driving force for the transformation of the CDO into the IWR zeolite, although further analysis is necessary to better understand this effect. In the present synthesis, choline hydroxide triggered the formation of 5MR units, while the *BEA zeolite provided aluminosilicate $4 \mathrm{MR}, 5 \mathrm{MR}$, and $6 \mathrm{MR}$ units. This means that the $4 M R$ and $6 M R$ units required for the growth of the IWR zeolite could only be supplied by the *BEA zeolite. Therefore, both choline hydroxide and the *BEA zeolite are indispensable, and the IWR zeolite can only be prepared by exploiting their cooperative directing effect.

\section{Conclusions}

The aluminogermanosilicate IWR zeolite was successfully prepared in the presence of both choline hydroxide and aluminosilicate *BEA zeolite. When the *BEA zeolite was replaced by other aluminum sources, IWR was not obtained. This suggests that the *BEA zeolite played a cooperative structure-directing role and served as heterogeneous seed in the synthesis of the IWR zeolite. The crystallization process was investigated by characterizing a series of solid products collected at different reaction times. The dissolution/decomposition of the *BEA zeolite was explicitly observed from the very beginning, while the CDO zeolite was shown to be an intermediate phase. A plausible mechanism for the cooperative synthesis of the IWR zeolite was also proposed. The choline hydroxide OSDA favored the formation of germanosilicate 5MR-based building units, while the decomposition of the *BEA zeolite heterogeneous seeds gave rise to enormous amounts of aluminosilicate 4MR, 5MR, and 6MR units. The reassembly of these building units in the presence of choline molecules that took place afterward is considered to be the crucial step in the synthesis of IWR zeolites. We believe that the structural similarity and common building units with the IWR zeolite enable the *BEA zeolite to serve as heterogeneous seed in the cooperative structure-directing synthesis. The present results provide a new example of cooperative structure-directing effects in the synthesis of microporous materials. With heterogeneous seeds providing building units that OSDAs may not be capable to provide, this new route opens up the possibility of preparing other zeolites that have not been accessible by traditional hydrothermal synthetic methods, as well as zeolites with novel framework structures.

\section{References}

[1] R. M. Barrer, P. J. Denny, J. Chem. Soc., 1961, 971-982.
[2] J. Li, A. Corma, J. Yu, Chem. Soc. Rev., 2015, 44, 7112-7127.

[3] A. W. Burton, S. I. Zones, Stud. Surf. Sci. Catal., 2007, 168, 137-179.

[4] P. Wagner, Y. Nakagawa, G. S. Lee, M. E. Davis, S. Elomari, R. C. Medrud, S. I. Zones, J. Am. Chem. Soc., 2000, 122, 263-273.

[5] A. W. Burton, G. S. Lee, S. I. Zones, Microporous Mesoporous Mater., 2006, 90, 129-144.

[6] A. W. Burton, S. I. Zones, S. Elomari, Curr. Opin. Colloid Interface Sci., 2005, 10, 211-219.

[7] X. Meng, F. S. Xiao, Chem. Rev., 2014, 114, 1521-1543.

[8] B. Xie, J. Song, L. Ren, Y. Ji, J. Li, F. S. Xiao, Chem. Mater., 2008, 20, 4533-4535.

[9] H. Zhang, Q. Guo, L. Ren, C. Yang, L. Zhu, X. Meng, C. Li, F. S. Xiao, J. Mater. Chem., 2011, 21, 9494-9497.

[10] H. Zhang, L. Chu, Q. Xiao, L. Zhu, C. Yang, X. Meng, F.-S. Xiao, J. Mater. Chem. A, 2013, 1, 3254-3257.

[11] Y. Kamimura, K. Itabashi, T. Okubo, Microporous Mesoporous Mater., 2012, 147, 149-156.

[12] K. Iyoki, K. Itabashi, W. Chaikittisilp, S. P. Elangovan, T. Wakihara, S. Kohara, T. Okubo, Chem. Mater., 2014, 26, 1957-1966.

[13] T. Yokoi, M. Yoshioka, H. Imai, T. Tatsumi, Angew. Chem. Int. Ed., 2009, 48, 9884-9887.

[14] K. Itabashi, Y. Kamimura, K. Iyoki, A. Shimojima, T. Okubo, J. Am. Chem. Soc., 2012, 134, 11542-11549.

[15] Y. Ji, Y. Wang, B. Xie, F.-S. Xiao, Comments Inorg. Chem., 2016, 36, 1-16.

[16] K. Iyoki, M. Takase, K. Itabashi, K. Muraoka, W. Chaikittisilp, T. Okubo, Microporous Mesoporous Mater., 2015, 215, 191-198.

[17] Y. Kamimura, K. Iyoki, S. P. Elangovan, K. Itabashi, A. Shimojima, T. Okubo, Microporous Mesoporous Mater., 2012, 163, 282-290.

[18] K. Iyoki, K. Itabashi, T. Okubo, Microporous Mesoporous Mater., 2014, 189, 22-30.

[19] B. Xie, H. Zhang, C. Yang, S. Liu, L. Ren, L. Zhang, X. Meng, B. Yilmaz, U. Muller, F.-S. Xiao, Chem. Commun., 2011, 47, 3945-3947.

[20] Y. Kamimura, W. Chaikittisilp, K. Itabashi, A. Shimojima, T. Okubo, Chem. - Asian J., 2010, 5, 2182-2191.

[21] Y. Kamimura, S. Tanahashi, K. Itabashi, A. Sugawara, T. Wakihara, A. Shimojima, T. Okubo, J. Phys. Chem. C, 2011, 115, 744-750.

[22] Q. Yu, Q. Zhang, J. Liu, C. Li, Q. Cui, CrystEngComm, 2013, 15, 7680-7687.

[23] T. Xue, L. Dong, Y. Zhang, H. Wu, Acta Phys.-Chim. Sin., 2018, 34, 920-926.

[24] M. Castro, R. Garcia, S. J. Warrender, A. M. Z. Slawin, P. A. Wright, P. A. Cox, A. Fecant, C. Mellot-Draznieks, N. Bats, Chem. Commun., 2007, 3470-3472.

[25] R. Xu, X. Shi, W. Zhang, Y. Xu, Z. Tian, X. Lu, X. Han, X. Bao, Phys. Chem. Chem. Phys., 2010, 12, 2443-2449.

[26] A. B. Pinar, L. Gomez-Hortiguela, J. Perez-Pariente, Chem. Mater., 2007, 19, 5617-5626.

[27] S. I. Zones, S.-J. Hwang, M. E. Davis, Chem.-Eur. J., 2001, 7, 1990-2001.

[28] L. Sierra de Saldarriaga, C. Saldarriaga, M. E. Davis, J. Am. Chem. Soc., 1987, 109, 2686-2691.

[29] A. Turrina, R. Garcia, P. A. Cox, J. L. Casci, P. A. Wright, Chem. Mater., 2016, 28, 4998-5012.

[30] V. Valtchev, J. L. Paillaud, H. Kessler, E. J. Creyghton, Microporous Mesoporous Mater., 1999, 33, 143-148.

[31] S. I. Zones, US Patent 4665110, 1986.

[32] K. Suzuki, T. Hayakawa, Microporous Mesoporous Mater., 2005, 77, 131-137.

[33] S. Sogukkanli, K. Iyoki, S. P. Elangovan, K. Itabashi, M. Takano, Z. Liu, S. Inagaki, T. Wakihara, Y. Kubota, T. Okubo, Microporous Mesoporous Mater., 2017, 245, 1-7. 
[34] S. Sogukkanli, K. Iyoki, S. P. Elangovan, K. Itabashi, T. Okubo, Chem. Lett., 2017, 46, 1419-1421.

[35] Y. Kubota, K. Itabashi, S. Inagaki, Y. Nishita, R. Komatsu, Y. Tsuboi, S. Shinoda, T. Okubo, Chem. Mater., 2014, 26, 1250-1259.

[36] R. Castañeda, A. Corma, V. Fornés, F. Rey, J. Rius, J. Am. Chem. Soc., 2003, 125, 7820-7821.

[37] M. Moliner, C. Martínez, A. Corma, Angew. Chem. Int. Ed., 2015, 54, 3560-3579.

[38] A. Corma, F. J. Llopis, C. Martínez, G. Sastre, S. Valencia, J. Catal., 2009, 268, 9-17.

[39] G. Sastre, A. Pulido, R. Castañeda, A. Corma, J. Phys. Chem. B, 2004, 108, 8830-8835.

[40] W. H. Fu, Z. Yuan, Z. Wang, Y. Wang, W. Yang, M.-Y. He, Dalton Trans., 2017, 46, 6692-6699.

[41] A. Cantín, A. Corma, M. J. Diaz-Cabanas, J. L. Jordá, M. Moliner, J. Am. Chem. Soc., 2006, 128, 4216-4217.

[42] A. B. Pinar, L. B. McCusker, C. Baerlocher, J. Schmidt, S. J. Hwang, M. E. Davis, S. I. Zones, Dalton Trans., 2015, 44, 6288-6295.

[43] L. Zhang, Y. Chen, J.-G. Jiang, L. Xu, W. Guo, H. Xu, X.-D. Wen, P. Wu, Dalton Trans., 2017, 46, 15641-15645.

[44] J. Pérez-Pariente, R. García, L. Gómez-Hortigüela, A. B. Pinar, in: J. Ceika, A. Corma, S. Zones eds, Zeolites and Catalysis: Synthesis, Reactions and Applications, Wiley-VCH, Weinheim, 2010, 107-130.

[45] S. Jin, Z. Feng, F. Fan, C. Li, Catal. Lett., 2015, 145, 468-481.

[46] C. Li, P. C. Stair, Catal. Today, 1997, 33, 353-360.

[47] G. Xiong, C. Li, Z. Feng, P. Ying, Q. Xin, J. Liu, J. Catal., 1999, 186, 234-237.

[48] F. Fan, Z. Feng, C. Li, Chem. Soc. Rev., 2010, 39, 4794-4801.

[49] Q. Guo, F. Fan, M. Guo, Z. Feng, C. Li, Chin. J. Catal., 2012, 33,
106-113.

[50] P. K. Dutta, D. C. Shieh, M. Puri, Zeolites, 1988, 8, 306-309.

[51] P. K. Dutta, K. M. Rao, J. Y. Park, J. Phys. Chem., 1991, 95, 6654-6656.

[52] Y. Yu, G. Xiong, C. Li, F. S. Xiao, Microporous Mesoporous Mater., 2001, 46, 23-34.

[53] J. Pérez-Pariente, J. Sanz, V. Fornés, A. Corma, J. Catal., 1990, 124, 217-223.

[54] G. Zhang, D. Wang, P. Feng, S. Shi, C. Wang, A. Zheng, G. Lü, Z. Tian, Chin. J. Catal., 2017, 38, 1207-1215.

[55] C. A. Fyfe, J. M. Thomas, J. Klinowski, G. C. Gobbi, Angew. Chem. Int. Ed., 1983, 22, 259-275.

[56] M. El-Roz, L. Lakiss, A. Vicente, K. N. Bozhilov, F. Thibault-Starzyk, V. Valtchev, Chem. Sci., 2014, 5, 68-80.

[57] E. Verheyen, L. Joos, K. Van Havenbergh, E. Breynaert, N. Kasian, E. Gobechiya, K. Houthoofd, C. Martineau, M. Hinterstein, F. Taulelle, V. Van Speybroeck, M. Waroquier, S. Bals, G. Van Tendeloo, C. E. A. Kirschhock, J. A. Martens, Nat. Mater., 2012, 11, 1059-1064.

[58] M. V. Shamzhy, O. V. Shvets, M. V. Opanasenko, P. S. Yaremov, L. G. Sarkisyan, P. Chlubna, A. Zukal, V. R. Marthala, M. Hartmann, J. Cejka, J. Mater. Chem., 2012, 22, 15793-15803.

[59] N. Kasian, G. Vanbutsele, K. Houthoofd, T. I. Koranyi, J. A. Martens, C. E. A. Kirschhock, Catal. Sci. Technol., 2011, 1, 246-254.

[60] N. Tsunoji, T. Ikeda, Y. Ide, M. Sadakane, T. Sano, J. Mater. Chem., 2012, 22, 13682-13690.

[61] Y. Lee, M. B. Park, P. S. Kim, A. Vicente, C. Fernandez, I.-S. Nam, S. B. Hong, ACS Catal., 2013, 3, 617-621.

[62] W. J. Roth, D. L. Dorset, Struct. Chem., 2010, 21, 385-390.

[63] W. J. Roth, P. Nachtigall, R. E. Morris, J. Čejka, Chem. Rev., 2014,

\section{Graphical Abstract}

Chin. J. Catal., 2019, 40: 856-866 doi: S1872-2067(19)63324-3

Cooperative structure-directing effect of choline cation and *BEA zeolite in the synthesis of aluminogermanosilicate IWR zeolite

Wenhua Fu, Zhiqing Yuan, Shaoqing Jin, Wei Liu, Zhendong Wang, Chuanming Wang, Yangdong Wang, Weimin Yang *, Ming-Yuan He * Sinopec Shanghai Research Institute of Petrochemical Technology; East China Normal University
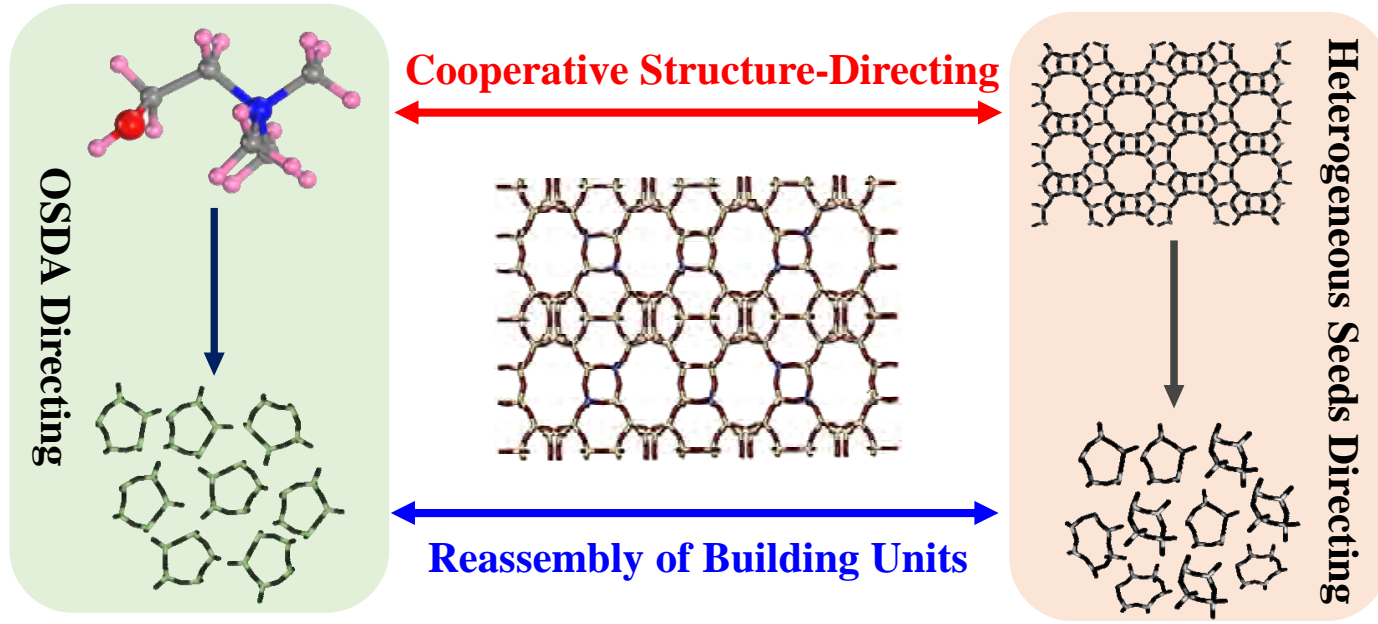

Cooperative structure-directing effect of choline cation used as organic structure-directing agent (OSDA) and *BEA zeolite used as heterogeneous seeds in the synthesis of IWR zeolite is disclosed for the first time. 
$114,4807-4837$.

[64] B. Marler, Y. Wang, J. Song, H. Gies, Dalton Trans., 2014, 43, 10396-10416.

[65] S. Goel, S. I. Zones, E. Iglesia, Chem. Mater., 2015, 27, 2056-2066.
[66] J. M. Newsam, M. M. J. Treacy, W. T. Koetsier, C. B. D. Gruyter, Proc. R. Soc. London, Ser. A, 1988, 420, 375-405.

[67] J. B. Higgins, R. B. LaPierre, J. L. Schlenker, A. C. Rohrman, J. D. Wood, G. T. Kerr, W. J. Rohrbaugh, Zeolites, 1988, 8, 446-452.

\title{
胆碱和*BEA分子篮在硅锗铝IWR分子篮制备中的协同导向效应
}

\author{
付文华 ${ }^{\mathrm{a}, \mathrm{b}}$, 袁志庆 ${ }^{\mathrm{a}}$, 金少青 ${ }^{\mathrm{a}}$, 刘 巍, 王振东 ${ }^{\mathrm{a}}$, 王传明 ${ }^{\mathrm{a}}$, 王仰东, \\ 杨为民 民, $^{\mathrm{*}}$, 何鸣元 ${ }^{\mathrm{b}, \#}$ \\ ${ }^{\mathrm{a}}$ 中国石化上海石油化工研究院, 绿色化工与工业催化国家重点实验室, 上海201208 \\ b华东师范大学化工与分子工程, 上海市绿色化学与化工过程绿色化重点实验室, 上海200062
}

摘要: 分子䇥的制备过程一般需要结构导向剂的参与. 结构导向剂主要包括碱(土)金属离子、有机胺或季铵盐为代表的有 机模板剂和固体晶种等三类. 研究合成凝胶中不同结构导向剂之间的作用对于理解分子篎晶化机理意义重大. 以往的研 究大都集中在模板剂-模板剂、模板剂-碱(土)金属离子和模板剂-同晶之间的相互作用, 迄今尚未有模板剂-异晶之间相互作 用研究的报道.

我们研究组首次发现模板剂和异晶在分子篮制备中存在协同导向效应. 在硅锗铝IWR分子篮的合成中, 我们考察了不 同的季铵碱模板剂和铝源, 发现只有使用胆碱作模板剂、*BEA分子筛作铝源才可以成功制得目标分子筛, 相同条件下不加 入*BEA分子篮或换用MOR、ZSM-5、MCM-22、USY分子篮及异丙醇铝等铝源都无法合成得到IWR分子篮. 这说明*BEA 分子篮在IWR分子篮的制备中起到了其他铝源所不具备的结构导向作用, 因此我们称之为合成IWR分子篮的“异晶”.

为了研究胆碱和*BEA分子篮之间的相互作用,进而揭示模板剂-异晶协同导向制备分子篮的一般规律与反应机理, 我 们制备了不同晶化时间的IWR分子笁样品, 使用X射线粉末衍射(XRD)、扫描电子显微镜(SEM)、紫外-拉曼光谱 (UV-Raman)、固体核磁共振(MAS NMR)和 $\mathrm{N}_{2}$ 物理吸附等手段对这些样品进行了表征. 结果显示, 加热过程中*BEA分子篮 首先发生溶解解离, $72 \mathrm{~h}$ 后该分子篮相完全消失; $12 \mathrm{~h}$ 开始出现CDO分子筛相, 随着晶化时间延长, CDO分子篮先增多后减 少, 在 $24 \mathrm{~h}$ 时达到最大值, $120 \mathrm{~h}$ 时消失, 说明该分子篮是晶化过程的一个中间相; IWR分子篎在 $12 \mathrm{~h}$ 开始出现, 此后结晶度 不断升高, 至168 h 晶化完全.

在上述表征的基础上, 我们提出了模板剂-异晶协同导向制备IWR分子篮的晶化机理. IWR分子篎的晶化分为以下 5 个 步骤: (1)*BEA分子篮溶解解离得到硅铝4元环、5元环和 6 元环等结构单元; (2)胆碱诱导形成硅锗5元环结构单元; (3) 硅锗 5 元环组装生成 $\mathrm{CDO}$ 分子篎; (4)CDO分子篮溶解解离形成硅锗5元环; (5)*BEA分子篎导向的结构单元与胆碱导向的结构 单元重组生成IWR分子篮. 其中, 步骤3 和 4 是一对可逆反应, 且可与步骤 5 同时进行; 随着反应物原料的不断消耗, 步骤5占 据主导, 从而导致 $\mathrm{CDO}$ 分子篮完全消失和IWR分子篮的结晶完成. 由于胆碱只导向生成5元环结构单元, 而构成IWR分子 篮骨架结构的 4 元环和 6 元环只能由*BEA分子篮提供, 因而模板剂和异晶在反应中都不可或缺, 二者起到协同导向的作用. 分析发现, *BEA分子笁与IWR分子篮具有共同的结构单元(4、5、6元环)和一定的结构相似性是其可以成为异晶、发挥协 同导向作用的关键.

上述协同导向法的关键在于模板剂和异晶分别导向生成部分结构单元, 再经重组得到目标分子篮. 这种方法有望用 于合成通过传统水热法难以得到的分子篮, 并且为新结构分子篮的开发提供新思路. 使用协同导向法制备更多种类分子 篮的研究正在进行中.

关键词: IWR分子篮; 协同导向效应; 有机模板剂; 胆碱; 异晶; *BEA分子篮

收稿日期: 2019-01-07. 接受日期: 2019-01-26. 出版日期: 2019-06-05.

*通讯联系人. 电话: (021)68462197; 电子信箱: yangwm.sshy@sinopec.com

\#通讯联系人. 电话: (021)62232213; 电子信箱: hemingyuan@126.com

基金来源：国家重点研发计划(2017YFB0702800); 国家自然科学基金(21802168, 21503280, 21603277); 中国石化集团.

本文的电子版全文由Elsevier出版社在ScienceDirect上出版(http://www.sciencedirect.com/science/journal/18722067). 